\title{
PENGARUH STRATEGI PEMASARAN TERHADAP PENINGKATAN VOLUME PENJUALAN PAKAIAN PADA TOKO GROSIR KADAFI COLLECTION DI KOTA SIGLI KABUPATEN PIDIE
}

\author{
Cut Italina ${ }^{1}$, Fakhrurrazi ${ }^{2}$ \\ Fakultas Ekonomi Universitas Jabal Ghafur
}

\begin{abstract}
ABSTRAK
Penelitian ini bertujuan untuk mengetahui Pengaruh Strategi Pemasaran Terhadap Peningkatan Volume penjualan Pakaian pada Toko Grosir Kadafi Collection di kota Sigli Kabupaten Pidie. Penelitian ini bertujuan utuk mengetahui pengaruh strategi pemasaran terhadap peningkatan volume penjualan pakaian pada Toko Grosir Kadafi Collection di kota Sigli. Dalam penelitian ini metode Analisis yang di gunakan adalah Regresi sederhana, sedangkan pengumpulan data di lakukan dengan cara wawancara, Responden penelitian sebanyak 70 orang konsumen Toko Grosir Kadafi Collection di Sigli yang di ambil secara purposive sampling. pengumpulan data menggunakan kuesioner yang di isi oleh responden berdomisili di Toko Grosir Kadafi Collection Sigli. Hasil penelitian ini menunjukkan bahwa secara simultan variabel strategi pemasaran berpengaruh signifikan terhadap peningkatan volume penjualan. Pengaruh strategi pemasaran trerhadap peningkatan volume penjualan dengan nilai $\mathrm{F}$ hitung sebesar 85,876 dengan tingkat signifikan sebesar 0,000. Uji statistik juga menunjukkan nilai $\mathrm{T}$ hitung sebesar 9,267 dengan tingkat signifikan sebesar 0,000 . secara parsial strategi pemasaran mempengaruhi peningkatan volume penjualan pada Toko Grosir kadafi Collection di kota Sigli.
\end{abstract}

\begin{abstract}
This study aims to determine the effect of marketing strategies on increasing sales volume of clothing at the Kadafi Collection Wholesale Store in the city of Sigli, Pidie Regency. This study aims to determine the effect of marketing strategies on increasing the volume of clothing sales at the Kadafi Collection Wholesale Store in the city of Sigli. In this study the analysis method used is simple regression, while data collection is done by interview, 70 respondents of the Kadafi Collection Wholesale Store consumers in Sigli were taken by purposive sampling. Data collection using questionnaires filled out by respondents domiciled in the Sigli Kadafi Collection Wholesale Store. The results of this study indicate that simultaneously marketing strategy variables significantly influence the increase in sales volume. The effect of the marketing strategy towards an increase in sales volume with a calculated $F$ value of 85.876 with a significant level of 0,000. Statistical tests also showed a calculated T value of 9.267 with a significant level of 0,000. the marketing strategy partially affects the increase in sales volume at the Gaddafi Collection Wholesale Store in the city of Sigli.
\end{abstract}

Kata Kunci: Strategi Pemasaran dan Volume Penjualan

\section{PENDAHULUAN}

\section{Latar Belakang}

Kehidupan pada masa sekarang ini adalah kehidupan dengan semakin komplek akan hal-hal yang menyangkut dengan bisnis atau perekonomian. Toko Grosir Kadafi Collection di kota Sigli. merupakan sebuah usaha perseorangan yang menjalankan 
usahanya dalam bidang pemasaran pakaian. Toko Grosir Kadafi collection di kota sigli sigli. juga ikut berperanserta dalam membantu konsumen memberi penjualan barang baik itu secara cash, maupun kredit pada beberapa Toko yang ada di beberapa daerah kecamatan. Antaranya daerah Saree, Padang Tiji, Grong-Grong, Batee, Garot, dan Kota Sigli, harapan tersebut demi membantu program pembangunan daerahterutama di sektor pemasaran. Untuk memperbanyak konsumen dan meningkatkan volume penjualan, Toko Grosir Kadafi Collection sigli. Harus membuat perencanaan keputusan yaitu keputusan dalam menetapkan strategi pemasaran yang tepat untuk di gunakan dimana Keputusan tersebut haruslah keputusan yang bijaksana efektif dan efisien.

\section{Tujuan Penelitian}

Tujuan penelitian dalam penelitian ini adalah:

a. Untuk mengetahui sejauh mana pengaruh strategi pemasaran terhadap peningkatan volume penjualan pakaian pada Toko Gosirkadafi Collection Sigli.

b. Untuk mengetahui apakah pengaruh strategi pemasaran terhadap peningkatan volume penjualan pakaian yang diterapkan oleh Toko Grosir Kadafi Collection Sigli merupakan strategi yang tepat untuk memasarkan pakaian sebagai alat kebutuhan setiap individu dalam usaha pemasaran.

\section{TINJAUAN PUSTAKA Pengertian Pemasaran}

Pemasaran merupakan salah satu kegiatan utama yang mesti dilakukan oleh perusahaan dalam mempertahankan kelangsungan hidup perusahaan, berkembang untuk mendapatkan laba. Semua perusahaan akan berusaha memasarkan produk atau jasa untuk dapat memenuhi kebutuhan konsumen serta dapat meningkatkan pendapatan usahanya. Philip Kotler (2009:5) mengemukakan bahwa pemasaran adalah sebuah proses kemasyarakatan dimana individu dan kelompok memperoleh apa yang mereka butuhkan dan inginkan dengan menciptakan, menawarkan, dan secara bebas mempertukarkan produk dan jasa yang bernilai dengan orang lain.

\section{Strategi Pemasaran}

Strategi pemasaran adalah logika pemasaran dimana perusahaan berharap untuk menciptakan nilai pelanggan dan mencapai hubungan yang menguntungkan (Kotler \& Armstrong, 2006:58).

Philip dan Kotler (2005:91) mendefinisikan strategi pemasaran sebagai seranngkaian tindakan terpadu menuju keunggulan kompetitif yang berkelanjutan. Ada dua faktor yang mempengaruhi strategi pemasaran adalah:

a. Faktor mikro, yaitu perantara pemasaran, pemasok, pesaing-pesaing dan masyarakat.

b. Faktor makro, yaitu georafi atau ekonomi, politik atau hukum, teknologi atau fisik, dan sosial atau budaya.

\section{Bauran Pemasaran (Marketing Mix)}

Bauran pemasaran (marketing mix) adalah kombinasi dari empat variabel atau kegiatan yang merupakan inti dari system pemasaran perusahaan, yakni: produk, struktur harga, kegiatan promosi, dan system distribusi.

Terdapat empat jenis bauran pemasaran sebagai berikut Boom dan Bitner (dalam Philip Kotler (2005:88) adalah sebagai berikut:

1. Produk (Product), yang menyangkut pemilihan barang atau jasa yang ditawarkan secara tepat.

2. Harga (Price), menyangkut penetapan harga jual barang yang sesuai dengan 
kualitas barang dan dapat dijangkau oleh konsumen.

3. Distribusi (Place), menyangkut pemilihan cara pendistribusian barang dan jasa sehingga sampai ke tangan konsumen.

4. Promosi (Promotion), menyangkut pemilihan kebijaksanaan promosi yang tepat, sesuai dengan barang atau jasa yang ditawarkan.

\section{Volume Penjualan}

Volume penjualan merupakan salah satu bentuk baku dari kinerja perusahaan. Berhasil tidaknya suatu perusahaan dapat dilihat dari kondisi volume penjualan secara keseluruhan. Menurut Swastha (2005:141), menyatakan bahwa volume penjualan merupakan penjualan bersih dari laporan laba perusahaan. Penjualan bersih diperoleh melalui hasil penjualan seluruh produk (produk lini) selama jangka tertentu, dan hasil penjualan yang diperoleh dari market share (pangsa pasar) yang merupakan penjualan potensial yang dapat terdiri dari kelompok teritorial dan kelompok pembeli saham jangka waktu tertentu.

\section{Kerangka Konseptual Penelitian}

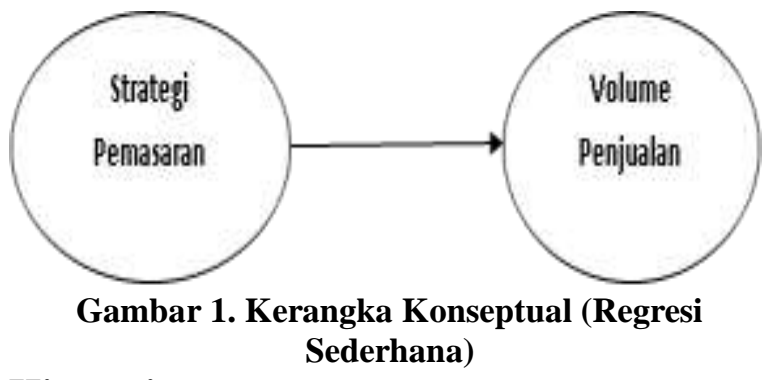

\section{Hipotesis}

Berdasarkan latar belakang penelitian, landasan teoritis penelitian yang telah di lakukan oleh peneliti sebelumnya, yang menjadi hipotesis dalam penelitian ini adalah Strategi pemasaran berpengaruh signifikan terhadap peningkatan volume penjualan pakaian pada Toko Grosir Kadafi Collection di Kota Sigli Kabupaten Pidie.

\section{METODE}

\section{Lokasi dan Objek Penelitian}

Penelitian ini di lakukan di kota sigli, untuk memperoleh data dalam penelitian ini di adakan penelitian pada toko Grosir kadafi collection sigli yang beralamat di jalan pembelian no 4 kota sigli, dan yang menjadi objek dalam penelitian ini adalahsejauh mana pengaruh strategi pemasaran dan peningkatan volume penjualan pakaian pada Toko Grosir Kadafi Collection Sigli.

\section{Populasi dan Sampel}

Populasi adalah keseluruhan dari objek yang akan di teliti. Sedangkan Sampel adalah bagian dari populasi yang akan dijadikan sebagai objek penelitian. Dalam penelitian ini jumlah Populasi penelitian adalah seluruh konsumen yang membeli berbagai perlengkapan pakaian pada Toko Grosir Kadafi Collection Sigli Kabupaten Pidie yang jumlahnya tidak di ketahui secara pasti (takhingga). Namun dalam menentukan jumlah sampel di lakukan dengan menggunakan metode "Convinience Sampling”. terhadap 70 pelanggan yang membeli di toko grosir kadafi collection sigli yaitu dengan cara sengaja dan simultan melakukan pemilihan dan pembagian kuesioner langsung pada lokasi usaha penjualan pakaian (Istijanto, 2005:34). Penelitian ini mempertimbangkan ukuran non statistic yaitu dengan pertimbangan menghemat waktu dan biaya serta tenaga bagi penulis dalam melakukan penelitian.

\section{Teknik Pengumpulan Data}

Untuk memperoleh informasi, maka penulis akanmelakukan pengumpulan data dengan teknik penyebaran koesioner, Koesioner merupakan daftar pertanyaan yang akan digunakan oleh periset untuk memperoleh data dari sumbernya secara langsung melalui proses komunikasi/wawancara atau dengan mengajukan pertanyaan tertulis. Peranan 
kuisioner sangat besar, karena semua pertanyaan yang diajukan periset termuat dalam kuisioner secara eksplisit. Dalam survei responden hanya perlu menjawab pertanyaan yang diajukan tanpa perlu memberi penjelasan lebih dalam kalau tidak diminta. (Istijanto:2005:66). Masing-masing pertanyaan/pernyataan di berikan altenatif pilihan jawaban Responden di minta untuk memilih jawaban yang mereka nilai paling cocok pada setiap item pertanyaan terkait.

\section{Peralatan Analisis Data}

Berdasarkan tujuan penelitian dan perumusan hipotesis yang telah di kemukakan sebelumnya, dapat di formulasikan bahwa Untuk melihat hubungan pengaruh starategi pemasaran terhadap peningkatan volume penjualan Pakaian maka akan digunakan analisa statistic melalui penggunaan regresi sederhana yang diolah melalui bantuan komputer pada program SPSS. Bentuk persamaan regresi sederhana dinyatakan sebagai berikut Husein Umar (2001:178):

$$
\mathbf{Y}=\mathbf{a}+\mathbf{b X}+\mathbf{e}
$$

\section{Keterangan:}

$$
\begin{aligned}
& Y=\text { Volume Penjualan } \\
& X=\text { Strategi Pemasaran } \\
& A=\text { konstanta } \\
& B=\text { koefisien regresi Strategi }
\end{aligned}
$$

Pemasaran

$$
\mathrm{E}=\text { error term }
$$

\section{HASIL PENELITIAN DAN PEMBAHASAN}

\section{Uji Reliabilitas}

Berdasarkan analisis reliabilitas uji kehandalan dapat diketahui Alpha untuk masing masing variabel di peroleh nilai Alpha lebih besar dari nilai 0,6, dengan demikian dapat disimpulkan bahwa pengukuran kehandalan memenuhi kredibilitas Cronbach Alpha.

\begin{tabular}{clcc}
\hline No & Variabel & $\begin{array}{c}\text { Nilai } \\
\text { Cronbach } \\
\text { Alpha }\end{array}$ & Keterangan \\
\hline 1 & $\begin{array}{l}\text { Strategi } \\
\text { pemasaran (X) }\end{array}$ & 0,921 & Handal \\
2 & $\begin{array}{l}\text { Volume } \\
\text { penjualan (Y) }\end{array}$ & 0,889 & Handal \\
\hline
\end{tabular}

Tabel di atas memperlihatkan bahwa nilai Cronbach alpha untuk masing- masing variabel yang di teliti lebih besar dari 0,60. Dengan demikian dapat di artikan kuesioner yang berhubungan di gunakan dalam pengumpulan data dinyatakan handal.

\section{Uji Validitas}

Untuk menguji Validitas di gunakan Person Correlation moment dimana dari hasil penelitian diperoleh bahwa koefisien korelasi untuk semua variabel dalam penelitian ini pada taraf kepercayaan 95 persen adalah signifikan, untuk lebih jelasnya menegenai Uji Validitas dapat di lihat pada lampiran.

\begin{tabular}{ccccc}
\multicolumn{5}{c}{ Tabel 4-2 Uji Validitas } \\
\hline Variabel & $\begin{array}{c}\text { Intem } \\
\text { perta } \\
\text { nyaan }\end{array}$ & $\begin{array}{c}\text { Nilai } \\
\text { Ritung }\end{array}$ & $\begin{array}{c}\text { Nilai } \\
\text { R tabel }\end{array}$ & $\begin{array}{c}\text { Keteran } \\
\text { gan }\end{array}$ \\
\hline Strategi & X1 & 0.901 & 0,396 & Valid \\
Pemasaran & X2 & 0.901 & 0,396 & Valid \\
X) & X3 & 0.901 & 0,396 & Valid \\
& X4 & 0.902 & 0,396 & Valid \\
& X5 & 0.934 & 0,396 & Valid \\
Volume & Y1 & 0.902 & 0,396 & Valid \\
penjualan & Y2 & 0.934 & 0,396 & Valid \\
(Y) & Y3 & 0.935 & 0,396 & Valid \\
& Y4 & 0.904 & 0,396 & Valid \\
& Y5 & 0.902 & 0,396 & Valid \\
\hline
\end{tabular}

\section{Hasil Uji Normalitas}

Pengujian normalitas di gunakan untuk melihat distribusi data penelitian dari masing-masing variabel telah menyebar secara normal atau tidak. Pengujian normalitas juga dapat di lihat dengan melihat sebaran standardized residual pada garfiknormal probalityplot. Suatu data dikatanberdistribusi normal apabila normal 
P-P Plot tidak menyimpang dari garis diagonal (Santoso dan Ashari, 2005:234). Hasil pengolahan data menghasilkan normal normal probality plot yang memperlihatkan bahwa garis yang menggambarkan data sesungguhnya mengikuti garis diagonal seperti terlihat dalam gambar berikut:

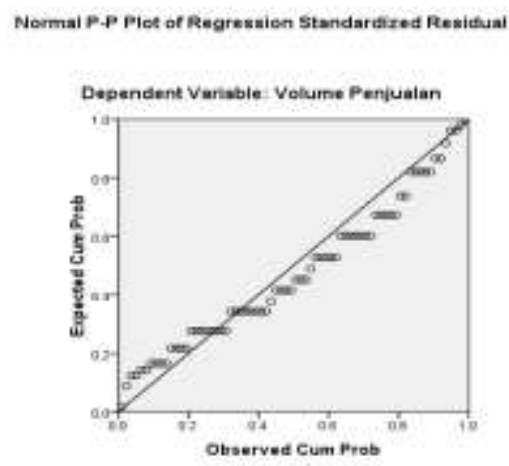

Gambar 2. Hasil Normalitas

Berdasarkan gambar di atas dapat dilihat bahwa garis yang menggambarkan data sesungguhnya akan mengikuti garis diagonalnya. Dengan demikian dapat di artikan bahwa data yang di gunakan dalam penelitian ini terdistribusi secara normal.

\section{Analisis Regresi Linier Sederhana}

Analisis regresi linier sederhana digunakan untuk mengetahui sejauh mana pengaruh strategi pemasaran terhadap peningkatan volume penjualan. Adapun model persamaan yang di gunakan adalah sebagai berikut:

$$
\mathbf{Y}=\mathbf{a}+\mathbf{b X}+\mathbf{e}
$$

Untuk menguji pengaruh variabel $\mathrm{X}$ terhadap $\mathrm{Y}$ digunakan persamaan regresi sederhana dengan olah data menggunakan program SPSS mengenai hasil olah data dapat di lihat di halaman lampiran penelitian. Dengan menggunakan peralatan analisis regresi sederhana dan perhitungan data menggunakan peralatan software Statistical package for serfice solution (SPSS) diketahui bahwa koefisien regresi masing-masing variabel seperti terlihat pada tabel di bawah ini:

Tabel 4-3 Uji Koefisien Regresi

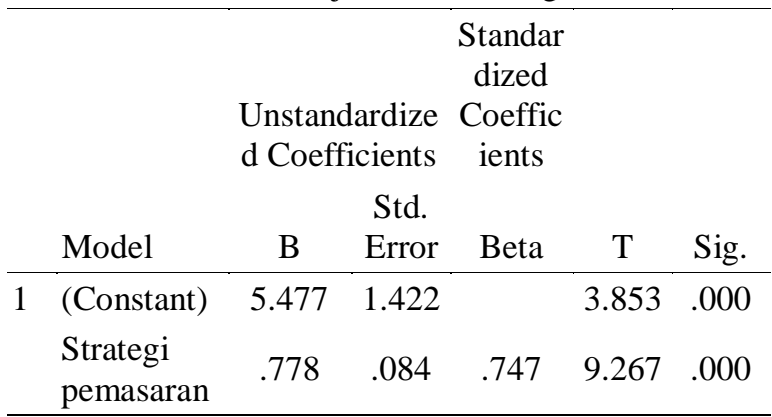

Berdasarkan prin out SPSS di atas, maka persamaan regresi sederhana yang memperlihatkan pengaruh strategi pemasaran terhadap peningkatan volume penjualan dapat di formulasikan sebagai berikut.qaa

$$
\mathbf{Y}=\mathbf{5 , 4 7 7 + 0 , 7 7 8} \mathrm{X}
$$

Persamaan di atas memperlihatkan koefisien ke dua variabel bernilai positif, yaitu sebesar 5,477 untuk variabel (Y), dan sebesar 0,778 untuk variabel (X). Hal ini berarti kedua variabel. Strategi pemasaran dan volume penjualan berpengaruh positif terhadap peningkatan volume penjualan.

\section{Koefissien Determinasi dan Korelasi}

Untuk mengetahui keeratan pengaruh strategi pemasaran terhadap peningkatan volume penjualan pakaian, digunakan koefisien korelasi $(\mathrm{R})$. selanjutnya untuk mengetahui besarnya variasi strategi pemasaran terhadap peningkatan volume penjualan pakaian di gunakan koefisien Determinasi $\left(\mathrm{R}^{2}\right)$. Kedua nilai koefisien tersebut dapat di lihat pada tabel 4-4 berikut:

Tabel 4-4 Nilai Koefisien Korelasi (R) dan Determinasi $\left(\mathrm{R}^{2}\right)$

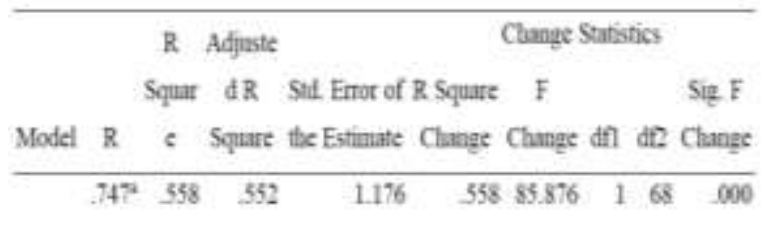

Swmber: Data primer diolah, (2012) 
Nilai koefisien Korelasi (R) sebesar 0,747 atau 74,7 persen. Selanjutnya nilai koefisien determinasi $\left(\mathrm{R}^{2}\right)$ menunjukan angka sebesar 0.558, dapat di artikan sebesar 55,8 persen Adanya pengaruh strategi pemasaran terhadap peningkatan volume penjualan.Sedangkan sisanya 44,2 persen lagi ditentukan oleh variabel lain, variabel selain strategi pemasaran yang tidak di bahas dalam penelitian ini seperti, kepuasan konsumen, gaya hidup konsumen, jasa. motivasi kerja karyawan, dan faktor-faktor lain.

\section{Pembuktian Hipotesis}

Untuk membuktikan hipotesis yang telah di kemukakan di gunakan peralatan statistik uji $F$ dan uji $t$ pada tingkat kepercayaan (Covidence Interval 95 persen). Uji F di gunakan untuk mengetahui signifikan pengaruh keseluruhan variabel Independen secara simultan terhadap pengaruh strategi pemasaran terhadap peningkatan volume penjualan pakaian pada toko Grosir kadafi collection sigli. Sedangkan Uji $t$ di gunakan untuk mengetahui signifikan pengaruh variabel independen secara persial terhadap peningkatan volume penjualan. Hasil pengujian statistikmenunjukan, nilai $\mathrm{F}$ hitung sebesar 85,876, sedangkan nilai $\mathrm{F}$ tabel menunjukkan angka sebesar 3,8964 Karena nilai $\mathrm{F}$ hitung > $\mathrm{F}$ tabel $(85,876>3,8964)$ dapat diartikan secara simultan strategi pemasaran mempengaruhi peningkatan volume penjualan pakaian pada toko grosir kadafi collection sigli, Sehingga hipotesis $\mathrm{Ha}$ diterima, Sebaliknya hipotesis Ho di tolak. Untuk lebih jelas mengenai hasil pengujian uji $F$ dan uji $t$ sebagai tolak ukur signifikan pengaruh variabel independen secara simultan dan parsial dapat di lihat pada tabel 4-5 berikut:
Tabel 4-5 Ringkasan Pengujian Hipotesis

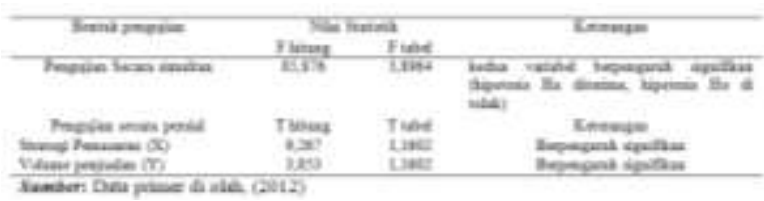

Berdasarkan Tabel 4-5 diatas dapat di lihat nilai t hitung Strategi Pemasaran (X) sebesar 9,267, dan sebesar 3,853 untuk variabel volume penjualan (Y). Dengan membandingkan nilai $t$ hitung dan nilait tabel yang tertera di atas, dapat di artikan bahwa nilai $t$ hitung $\mathrm{X}$ dan nilai $\mathrm{t}$ hitung $\mathrm{Y}$ lebih besar di bandingkan nilai $t$ tabel, hal ini berarti secara parsial kedua variabel tersebut berpengaruh signifikan terhadap peningkatan volume penjualan pakaian pada toko grosir kadafi collection sigli, berarti Ha di terima Ho di tolak. Sebaliknya bila nilai t hitung lebih kecil di bandingkan nilai t tabel, hal ini berarti variabel $\mathrm{X}$ secara parsial tidak berpengaruh signifikan terhadap peningkatan volume penjualan pakaian pada toko grosir kadafi collection sigli berarti Ho di terima dan Ha di tolak.

\section{SIMPULAN (PENUTUP)}

Kesimpulan penelitian ini adalah:

1. Hasil penelitian menunjukan bahwa terdapat pengaruh positif antara strategi pemasaran terhadap peningkatan volume penjualan pakaian pada Toko Grosir Kadafi Colllection di Kota Sigli Kabupaten Pidie.

2. Untuk meningkatkan volume penjualan pakaian pada Toko Grosir kadafi Collection kota Sigli Kabupaten Pidie sangat tergantung pada strategi-strategi pemasaran yang di jalankan oleh perusahaan.

3. Hasil pengujian statistik menunjukan nilai $\mathrm{F}$ hitung lebih besar dari $\mathrm{F}$ tabel di mana nilai $\mathrm{F}$ hitung sebesar $(85,876>3,8964)$, Sehingga $\mathrm{Ha}$ diterima dan sebaliknya hipotesis Ho di tolak yang berarti kedua 
variabel secara simultan berpengaruh signifikan terhadap peningkatan volume penjualan pakaian pada Toko Grosir kadafi collection di Kota Sigli Kabupaten Pidie.

4. Dari Hasil olah data juga dapat di tunjukkan strategi pemasaran berpengaruh positif terhadap peningkatan volume penjualan. Pengruh ini di uji dengan uji t hitung sebesar 3,853 untuk variabel volume penjualan dan sebesar 9,267 untuk variabel strategi pemasaran.

\section{DAFTAR PUSTAKA}

Basu Swastha, Irawan, (2005). Manajemen

Pemasaran Modern. Liberty,

Yogyakarta.
Istiyanto, Bekti. Pangestuti, Sri dan Nur

Aeni, Eni, (2006). Evaluasi Keberhasilan.

Kotler dan Armstrong, (2006). Dasar-dasar

Pemasaran, Prenhallindo, Jakarta.

Kotler, Philip, (2005). Manajamen

Pemasaran, Jilid 1 dan 2. Jakarta:

PT. Indeks Kelompok Gramedia.

Santoso, Singgih. (2005). SPSS Mengolola Data Statistik Secara Profesional, Alex Media Komputindo, Jakarta.

Umar, Husen, (2001), Metodelogi Penelitian Aplikasi Dalam Pesaran. PT. Grmedia Pustaka Utama. 